\title{
Perceived Learning Outcomes and Interaction Mode Matter: Students' Experience of Taking Online EFL Courses During COVID-19
}

\author{
Yaqiong Cui ${ }^{1}$ \\ ${ }^{1}$ Department of Foreign Languages, University of Chinese Academy of Sciences, Beijing, China \\ Correspondence: Yaqiong Cui, University of Chinese Academy of Sciences (Yuquan Campus), A19 Yuquan Rd, \\ Shijingshan District, Beijing 100049, People's Republic of China.
}

Received: April 7, 2021

doi: 10.5539/elt.v14n6p84
Accepted: May 13, 2021

Online Published: May 25, 2021

\begin{abstract}
The recent health emergency has changed the teaching mode globally, with traditional classroom teaching shifting to online platforms. This created challenges for both foreign/second language teachers and learners. Some recent studies investigated the challenges brought by online teaching from the teachers' perspective; however, little is known about how students perceive the effectiveness of online language learning based on their experiences. Therefore, this study surveyed 252 Chinese students who took online EFL courses during the pandemic through an online survey platform. Survey questions include 75 statements regarding EFL learner's perceived experience in taking online EFL courses, such as learning platforms, teaching and assessment methods, interaction mode, classroom management, and the effectiveness of online courses. Students rated each statement on a 5-point Likert Scale. Open-ended questions further targeted students' suggestions to improve the quality of online language courses. Results from analysis of variance, factor analysis, and multiple linear regression analysis showed that students perceived the interactional opportunity and learning outcome as the most important factors in their online EFL learning experiences. Students generally showed a positive attitude toward their online language learning experiences and a high level of participation in synchronized online EFL courses. They further suggested a mixture of traditional and online class as an ideal teaching model for EFL learning, especially in the face of public crisis. Findings from this study may shed light on language curriculum design, language teacher education, and educational technology.
\end{abstract}

Keywords: EFL learning, online courses, student perceptions, pandemic

\section{Introduction}

\subsection{Background}

The recent COVID-19 pandemic has created enormous challenges worldwide (Adedoyin \& Soykan, 2020; Almazova, Krylova, Rubtsova, \& Odinokaya, 2020; Khatoony \& Nezhadmehr, 2020; Sepúlveda-Escobar \& Morrison, 2020), especially in the field of education. Responding to the global health emergency, China's Ministry of Education has put forward the "non-stop classes" policy in the spring of 2020 at all levels of education during the lockdown period, which has prompted schools in China to move the courses from the traditional face-to-face classrooms to online platforms, signaling a remarkable change in teaching mode (Dhawan, 2020). The integration of technology in education has greatly facilitated learning as teachers and students can extend their physical classrooms and engage in interaction in virtual settings (Daymont, Blau, \& Campbell, 2011; Smith, 2005), making learning more interesting and effective (Al-Ghamdi, Almansoob, \& Alrefaee, 2019; Medriano \& Bautista, 2020).

Given its emphasis on self-directed and collaborative learning, online education has been particularly welcomed in higher education institutions. However, despite the increasing popularity of online learning and computer-assisted learning in the past two decades, the traditional classroom teaching still prevails in higher education and is favored by students (e.g., Lowenthal, Bauer, \& Chen, 2015; Tichavsky, Hunt, Driscoll, \& Jicha, 2015) and teachers (e.g., McNair-Crews, 2015). Although the delivery of online courses is relatively easier and less constrained by time and physical space, teachers and students still face great challenges to move all the courses and communication online. This may be caused by a number of reasons, such as the inequitable access to computers, laptops or smartphones in education, the unbalanced access to internet, and teachers' general lack of digital technology literacy over the world. Moreover, online teaching requires teachers to provide a variety of teaching materials, adopt different classroom management methods, modify the teaching processes and interaction mode, and achieve the same level 
of learning outcomes, if not higher. Several studies have investigated teachers' perceptions toward their online teaching experiences (e.g., Luo, Ma, \& Yao, 2020; McNair-Crews, 2015) and indicated that teachers generally perceived distance education to be beneficial; however, classroom instruction has strengths that cannot be complemented by online teaching. As students also form an integral part of teaching practices and how students actually experience with the teaching process may influence their motive and desire to learn online (Lin, Zhang, \& Zheng, 2017), there is a pressing need to understand students' perceived experiences of the new education mode. Attending to and addressing students' needs can also offer pedagogical insights for building effective online learning environment, help with the online course development (van der Kleij, 2019), and promote sustainable online learning (Zhang, Yin, Nie, \& Tang, 2016) in the post-corona era.

\subsection{Factors Influencing Student Experiences in Online Learning}

Earlier investigation of students' learning experiences primarily concerned e-learning and MOOC education, focusing on the general discussion of the development of MOOCs, the curriculum design and improvement, the transformation of teaching mode, the developmental trend of MOOCs in the future, and the education reform in higher education. Students' general learning outcomes were also discussed. As more research focused on how college students perceived their online learning experiences, various influencing factors have been identified. Some factors regard the structure and content of online curriculum (e.g., Yang \& Durrington, 2010). For example, Song, Singleton, Hill, and Koh (2004), Wu et al. (2014), and Nassoura (2020) all found that course design is an important component in students' online learning experiences and their satisfaction with the courses. Similarly, Fedynich, Bradley, and Bradley (2015) found that the varying instructional design is very important to facilitate students' desire to learn. On the other hand, Yang and Durrington (2010) claimed that online course structure is the main factor that affects students' perceptions of the quality of online courses.

Other factors concern the characteristics of the online platforms (Chen, 2017), online learning environment (Cole, Lennon, \& Weber, 2019; Damnjanovic et al., 2015; Song et al., 2004), the quality of online teaching resources and materials (Damnjanovic et al., 2015; Horvat et al., 2015; Paechter, Maier, \& Macher, 2010; Thurmond, Wamback, Connors, \& Frey, 2002; Surani \& Hamidah, 2019), as well as the availability of technical support of the platforms (Chen, 2017; Fedynich, Bradley, \& Bradley, 2015). These features are all found to have great impacts on students' learning behaviors and motivation in their online learning experiences.

Some other studies found that the teaching-related factors may influence students' perceived online learning experiences. One such factor regards the design of learning activities in online learning (Cole, Lennon, \& Weber, 2019; Horvat et al., 20151; Martin \& Bolliger, 2018; Sakulwichitsintu et al., 2015), and others concern teacher-student and student-student interactions in online courses. A large body of research documented the importance of instructor feedback in online education (Eom, Wen, \& Ashill, 2006; Paechter et al., 2010; Palmer \& Holt, 2010; Tichavsky, Hunt, Driscoll, \& Jicha, 2015; Vonderwell, 2003) and argued that feedback is a critical issue that affects students' satisfaction with their online learning (Fedynich, Bradley, \& Bradley, 2015). For instance, using factor analysis, reliability analysis, and hierarchical multiple regression, Yang and Durrington (2010) found that peer interactions and instructor feedback are the main factors that affect students' perceptions of online course quality. Horvat et al. (2015) also found that the average waiting time for a response and feedback quality may influence students' online learning experiences. When the feedback was delayed, students expressed feelings of stress, frustration, and confusion (Hara \& Kling, 2000; Vonderwell, 2003). Feedback from the instructors was also highly correlated with students' satisfaction with their online courses (Shea et al., 2003), engagement (Baker, 2010; Gray \& DiLoreto, 2016; Martin, Wang, \& Sadaf, 2018), and learning outcomes (Alraimi et al., 2015; Damnjanovic et al., 2015; Eom, Wen, \& Ashill, 2006). Many researchers also indicated that peer-interactions are an important element in developing a learning community, which dramatically affects students' online learning experience (e.g., Song et al., 2004). There are also studies focusing on students' perceived learning outcomes. For example, Song et al. (2004) studied 76 graduate students' perceptions of the useful and challenging components of online learning and found that the difficulty in understanding instructional goals posed challenges to their online learning experiences. Alraimi et al. (2015) also reported that students' intention of MOOC continuous use is associated with students' perceived gain in the online courses.

Previous research also found that student-related variables may influence students' online learning experiences. For instance, Song et al. (2004) found that students' online technology literacy, time management skills, and motivation were important components of success in online courses. Other individual factors that impact students' perceived online learning experiences include students' learning process (Paechter et al., 2010), learning style (Eom, Wen, \& Ashill, 2006), self-efficacy (Alhamami, 2019), and self-regulated learning (Tichavsky, Hunt, Driscoll, \& Jicha, 2015). In a large-scale questionnaire survey of 209,099 students from 334 Chinese universities, 
Chen and Jia (2020) found that students' gender, majors, education level, school location, school type, and online network literacy all have significant effects on students' perceived online learning experiences.

This bulk of research indicates that students' online learning experiences are determined by a variety of factors, and previous research has investigated these factors from different perspectives. However, very few studies have specifically looked at students' online learning experiences in language courses which highly value effective face-to-face interaction and timely feedback, especially in non-English-speaking context such as Asian countries. In one study, Ajmal, Alrasheedi, Keezhatta, and Yasir (2020) demonstrated how Google Classroom, Moodle, WhatsApp, and Instagram were utilized in English classes in Pakistani universities. They found that although teachers and learners benefited from using online technology in learning English, these technological tools cannot be recognized as complete alternatives to traditional face-to-face classrooms. Embracing the largest number of EFL learners, China has also made great efforts in implementing online EFL teaching during the COVID-19 period. Given that English is a required course in most of the higher education institutions in China, how EFL courses are delivered online during the pandemic in which EFL teachers are largely unprepared deserves researchers' attention. In addition, most of the previous studies centered their discussions on asynchronized or computer-assisted online teaching in which students' individual characteristics and online environment may have a greater impact on their perceived learning experience online. Issues related to synchronized or livestreamed online courses are seldom addressed. Moreover, no previous studies have examined the large-scale implementation of online learning in a time of social crisis in which online learning is considered as a required alternative to traditional classrooms, which has caused bewilderment among EFL teachers who are used to classroom teaching and students who consider real-time communication and timely responses as vitally important in English courses. Furthermore, previous studies mainly treat online courses as an exploratory move which often involve highly motivated students and fully prepared teachers, no studies have specifically examined when online teaching becomes a requirement instead of an option and when teachers and students are thrown into a reality for which they are largely unprepared (MacIntyre, Gregersen, \& Mercer, 2020).

Thus, aiming to investigate the general situation of online English teaching in Chinese universities during the COVID-19 period and the influencing factors of EFL learners' online learning experiences, this study is guided by the following research questions:

1) What is the situation of EFL learning in China during the pandemic?

2) What is students' experience in taking online EFL courses like?

3) What are the factors that influence students' experiences in learning EFL online?

\section{Research Methodology}

\subsection{Participants}

Data were collected through questionnaire survey in which students were asked to reflect upon their experiences with the online EFL courses. The questionnaire was designed in an online survey platform in early June 2020 and distributed to students who had enrolled in online EFL courses in the spring semester of 2020 through WeChat (Note 1) class groups, and the students were encouraged to share the survey link to other potential participants in other higher institutions across China. Within two weeks, 252 students (18-26 years old, 164 males and 88 females) responded to the survey. The demographic information shows that $54.8 \%$ of the schools are located in major cities in China, and the rest are located in relatively less developed areas. Among these schools, $54 \%$ are prestigious universities recognized by either the "Double-First Class" initiative or the "985/211" projects (Note 2). The student respondents represent a broad range of majors (mostly science majors) and grade levels (from freshmen to first-year doctoral students), making the participant samples quite representative.

\subsection{Questionnaire Items}

Survey questions include 75 statements regarding respondents' demographic information, EFL learning platforms used, class delivery mode, teaching methods, classroom interaction, assessment method, classroom management, learning process experiences, and the effectiveness of online EFL courses. Students rated each statement on a 5-point Likert Scale, with 1 indicating strongly agree and 5 indicating strongly disagree. The survey items were modified from a large-scale survey conducted in a Chinese university (Chen \& Jia, 2020), with more items added based on the author's interviews and casual conversations with individual students. The survey questions were piloted for two rounds with a separate group of students before they were sent out to the participants. Ambiguous and repetitive items were removed based on pilot participants' feedback. The overall reliability (Cronbach $\alpha=0.97$ ) and validity $(\mathrm{KMO}=0.93$, Bartlett sphericity test: Chi-square $=16224.96, \mathrm{df}=2775, \mathrm{p}=.000)$ of the scale are very good. 


\subsection{Data Analysis}

Data analyses were performed on SPSS 26. Quantitative results were first descriptively presented to show the overall situation of online EFL teaching in China, and then were submitted for one-way ANOVA to examine the effect of students' background information (e.g., gender, school location, school type, grade level, major, previous experiences in online learning, type of courses taken) on their experiences in online EFL learning. Data were then submitted for principal component analysis to determine the factor structure of each scale in which five factors (i.e., teaching platform, teaching method, interaction mode, teaching process, and learning outcome) were identified. The criteria used to identify the data structure are the Kaiser-Meyer-Olkin (KMO) and Bartlett's sphericity test. The high KMO coefficient (i.e., > 0.80) means that each variable in the scale will be perfectly predicted by other variables and Bartlett Sphericity Test shows the suitability of the sample to factor analysis. As shown in Table 1, the reliability (Cronbach $\alpha$ ) and validity (KMO and Bartlett sphericity test) of each factor are very good. To identify the scale, two criteria were adopted to determine in which factors the items were loaded and which items should remain in the scale: the maximum factor load values that are above .60 , indicating a high level of relationship, and the overlapping factor load values in which the difference between the maximum two factor load values of an item is above .10. Based on these criteria, the items in each factor were identified (see Table 5 for details).

Table 1. Reliability, validity, and sample questions of each factor $(n=252)$

\begin{tabular}{lllll}
\hline Scale & Item No. & Cronbach $\alpha$ & KMO & Bartlett sphericity test \\
\hline Teaching platform & 4 & 0.89 & 0.81 & Chi-square $=738.52, \mathrm{df}=6, \mathrm{p}=.000$ \\
Teaching method & 15 & 0.95 & 0.94 & Chi-square=2585.93, df $=105, \mathrm{p}=.000$ \\
Interaction mode & 6 & 0.86 & 0.83 & Chi-square $=672.78, \mathrm{df}=15, \mathrm{p}=.000$ \\
Learning process & 11 & 0.93 & 0.93 & Chi-square $=1747.22, \mathrm{df}=55, \mathrm{p}=.000$ \\
Learning outcome & 9 & 0.95 & 0.92 & Chi-square $=2078.47, \mathrm{df}=36, \mathrm{p}=.000$ \\
\hline
\end{tabular}

Next, data were analyzed by using multiple linear regression model, with students' perceived online EFL learning experiences being the dependent variable and the influencing factors being the independent variables, to investigate the degree of each factor on students' online EFL learning experiences. Open-ended questions further targeted students' elaboration on their learning experiences and suggestions to improve the quality of online language courses, serving as the base for qualitative analysis to supplement the quantitative results, which will make the conclusions more convincing and reliable.

\section{Results and Findings}

In this section, descriptive statistics are presented first to show the overall situation of EFL learning in China during the pandemic, including the learning platforms used by Chinese EFL instructors, delivery mode, teaching and assessment methods of EFL courses, as well as students' self-reported engagement in online EFL courses, followed by results of analysis of variance and multiple regression to identify the influencing factors of students' perceived online learning experiences.

\subsection{Descriptive Statistics}

Table 2 presents the online EFL learning platforms used by Chinese students during the pandemic. As shown in Table 2, among these online platforms, synchronized teaching on Tencent Meeting, Tencent Classroom, or Zoom was most widely adopted (48.09\%), followed synchronized or asynchronized teaching on university-developed platforms (29.95\%). Students also reported using instant messaging systems, such as WeChat, Tencent QQ, and Ding Talk, as supplementary tools in online learning. Learning resources on MOOCs were seldom used for online learning by EFL teachers in China (7.16\%).

Table 2. Online EFL learning platforms used by students $(n=252)$

\begin{tabular}{ll}
\hline Online platforms & Percentage \\
\hline Tencent Meeting, Tencent Classroom, Zoom & $48.09 \%$ \\
Platforms hosted by individual universities & $29.95 \%$ \\
WeChat, Tencent QQ, Ding Talk & $11.15 \%$ \\
MOOCs & $7.16 \%$ \\
Others & $3.66 \%$ \\
\hline
\end{tabular}


Table 3 shows the delivery method of online EFL courses in China. Among these course delivery modes, teachers preferred to have students attend the livestreamed class sessions on the platforms that are endorsed by the university and held regular class sessions as in traditional classrooms (41.05\%). About $47.79 \%$ of the teachers opted to ask students to preview the learning materials online and have students either discuss the main points in class or complete assignments offline. There were approximately $10 \%$ of the teachers who preferred to have students study the relevant learning resources provided by MOOCs.

Table 3. Delivery method of online EFL courses $(n=252)$

Delivery method of online EFL courses have regular classes.

Percentage

Students learn the PowerPoint slides uploaded to the platform approved by the school before class and have discussions with the teacher during the class time.

$41.05 \%$

Students learn the audios or videos uploaded to the platform approved by the school and finish the after-class assignments.

Students learn the audios or videos uploaded to the platform approved by the school before class and have discussions with the teacher during the class time.

The teacher asks students to learn similar courses on MOOCs but does not design class-specific tasks.

The teacher asks students to learn similar courses on MOOCs and designs class-specific tasks. $\quad 5.26 \%$

Table 4 shows student perceptions of their engagement in online EFL courses. As shown in Table 4, students rated their participation in online EFL courses between 1.68 and 2.32, which is lower than 3, indicating that students' participation in all aspects of their online EFL learning is relatively high.

Table 4. Student perceptions of their engagement in online EFL courses $(n=252)$

\begin{tabular}{lll}
\hline Student perceptions toward their engagement in online courses $(\mathrm{n}=252)$ & Mean & $\mathrm{SD}$ \\
\hline I always preview and review lessons & 2.32 & 0.96 \\
I always carefully study the course content & 1.86 & 0.80 \\
I always seek opportunities to interact with teachers & 2.29 & 0.94 \\
I always participate actively in class discussions & 2.03 & 0.93 \\
I always complete after-class assignments in time & 1.68 & 0.77 \\
I always seek opportunities to interact with classmates & 2.27 & 0.94
\end{tabular}

It seems that EFL teachers in China tended to use school-endorsed online teaching platforms that support synchronized teaching mode rather than the ready-to-use learning materials available online, such as MOOCs. This may be because such a teaching mode can simulate the face-to-face classroom in which teachers can record students' attendance, supervise the learning process, modify the teaching materials, promote interactions (Adnan \& Anwar, 2020), and better engage students in EFL learning (Martin \& Bolliger, 2018). This finding is further supported by students' self-reported engagement level in their online EFL courses (mean=2.08).

The rest of the statements in the survey were clustered into 5 factors for the ease of analysis based on the two criteria described in Section 2.3. Table 5 summarizes the descriptive statistics of each factor. Students generally rated their online EFL learning experience as 2.02, which is lower than the theoretical median of 3, indicating that students' overall evaluation of online EFL learning experience is quite good. Specifically, the evaluation scores of teaching platform, teaching method, interaction mode, teaching process and learning outcomes are 1.42, $1.64,2.15,2.48$, and 2.40 , respectively. 
Table 5. Descriptive statistics of each factor

\begin{tabular}{|c|c|c|}
\hline Factor & Items & Mean \pm SD \\
\hline \multirow{4}{*}{$\begin{array}{l}\text { Teaching } \\
\text { platform } \\
\text { (4 items) }\end{array}$} & Internet speed is important in online EFL learning. & $1.39 \pm 0.67$ \\
\hline & Stability of online platforms is important in online EFL learning. & $1.35 \pm 0.62$ \\
\hline & Quality of audios and videos is important in online EFL learning. & $1.34 \pm 0.61$ \\
\hline & Convenience in using tools is important in online EFL learning. & $1.63 \pm 0.77$ \\
\hline \multirow{15}{*}{$\begin{array}{l}\text { Teaching } \\
\text { method } \\
\text { (15 items) }\end{array}$} & The teaching content is interesting. & $1.58 \pm 0.73$ \\
\hline & Teachers choose the appropriate way of teaching online. & $1.56 \pm 0.64$ \\
\hline & Teachers share handouts or related learning materials. & $1.55 \pm 0.65$ \\
\hline & The teaching content is very clear. & $1.46 \pm 0.66$ \\
\hline & The tempo of teaching is appropriate. & $1.54 \pm 0.67$ \\
\hline & Teachers give reasonable preview and review tasks. & $1.65 \pm 0.71$ \\
\hline & Teachers give after-class assignments. & $1.81 \pm 0.78$ \\
\hline & Teachers provide interactional opportunities. & $1.58 \pm 0.71$ \\
\hline & Teachers give timely feedback to assignments and inquiries. & $1.62 \pm 0.70$ \\
\hline & Teachers attend to students' individual personalities and needs. & $1.75 \pm 0.78$ \\
\hline & Teachers speak English fluently and authentically. & $1.63 \pm 0.74$ \\
\hline & The difficulty of the teaching materials is appropriate. & $1.69 \pm 0.76$ \\
\hline & Teachers provide a variety of forms of learning materials. & $1.72 \pm 0.77$ \\
\hline & Teachers often encourage students. & $1.76 \pm 0.88$ \\
\hline & Teachers give feedback to individual students. & $1.77 \pm 0.87$ \\
\hline \multirow{6}{*}{$\begin{array}{l}\text { Interaction } \\
\text { mode } \\
\text { items })\end{array}$} & Teachers ask students to check in. & $2.18 \pm 0.94$ \\
\hline & Teachers call on students' names in class. & $2.22 \pm 0.96$ \\
\hline & Teachers provide opportunities for group discussions. & $1.87 \pm 0.89$ \\
\hline & Teachers have students work on group project. & $1.93 \pm 0.94$ \\
\hline & Teachers give pop-up quizzes in class. & $2.08 \pm 0.88$ \\
\hline & Show teachers' and students' real-time videos & $2.61 \pm 1.23$ \\
\hline \multirow{11}{*}{$\begin{array}{l}\text { Learning } \\
\text { process } \\
\text { (11 items) }\end{array}$} & Online EFL courses are easier for teachers to know students' learning status. & $2.62 \pm 1.13$ \\
\hline & Online EFL courses are easier for teachers to give feedback to students. & $2.43 \pm 1.06$ \\
\hline & Online EFL courses can promote interactions between students. & $2.71 \pm 1.21$ \\
\hline & Students are more active in online EFL courses. & $2.50 \pm 1.17$ \\
\hline & The learning materials in online EFL courses are richer. & $2.30 \pm 1.04$ \\
\hline & Assessment in online EFL courses is fairer. & $2.86 \pm 1.12$ \\
\hline & It is easier to complete online assignments. & $2.45 \pm 1.04$ \\
\hline & Learning English online is more reasonable. & $2.56 \pm 1.00$ \\
\hline & Online EFL courses are easier to understand. & $2.52 \pm 1.00$ \\
\hline & Teachers' pronunciation is clearer in online EFL courses. & $2.37 \pm 0.99$ \\
\hline & I have more freedom in online EFL courses. & $1.92 \pm 0.81$ \\
\hline \multirow{9}{*}{$\begin{array}{l}\text { Learning } \\
\text { outcome } \\
\text { (9 items) }\end{array}$} & Online EFL courses improved my reading skill in English. & $2.37 \pm 0.89$ \\
\hline & Online EFL courses improved my writing skill in English. & $2.40 \pm 0.86$ \\
\hline & Online EFL courses improved my speaking skill in English. & $2.49 \pm 0.99$ \\
\hline & Online EFL courses improved my listening skill in English. & $2.22 \pm 0.90$ \\
\hline & Online EFL courses improved my communicative competence in English. & $2.48 \pm 0.95$ \\
\hline & Online EFL courses improved my critical thinking ability. & $2.37 \pm 0.91$ \\
\hline & Online EFL courses improved my research ability. & $2.46 \pm 0.92$ \\
\hline & I become more and more interested in EFL learning. & $2.39 \pm 0.86$ \\
\hline & I become more and more confident in learning a foreign language. & $2.40 \pm 0.88$ \\
\hline
\end{tabular}




\subsection{Analysis of Variance on Students' Background Factors}

Independent sample t-test and one-way ANOVA were performed to investigate the effect of characteristics of participants on their perceived experiences in online EFL courses. Independent sample t-test shows that students' gender did not show significant difference in learning experience $\left(\mathrm{Mean}_{\text {male }}=2.37 \pm 0.70\right.$, Mean $_{\text {female }}=2.45 \pm 0.59, \mathrm{t}=$ $-0.85, p=.40$ ), which means that all samples of different genders show consistency in their learning experience. One-way ANOVA shows that different types of universities $(\mathrm{F}=1.04, p=.38)$ and students' school year $(\mathrm{F}=1.73$, $\mathrm{p}=.11$ ) did not show significant difference in their online learning experience. However, students' previous online learning experience before the epidemic is found to be significant $(\mathrm{F}=2.48, \mathrm{p}=.044)$, indicating that students who previously took online courses perceived their experiences differently than those who had not (see Table 6). Generally, students who attended online courses before COVID-19 tended to have better experiences in EFL online learning than those who occasionally or never took online courses before the epidemic.

Table 6. One-way ANOVA on students' previous experience in online learning $(\mathrm{n}=252)$

\begin{tabular}{llllllll}
\hline & Always $(\mathrm{n}=41)$ & Often $(\mathrm{n}=17)$ & General $(\mathrm{n}=43)$ & $\begin{array}{l}\text { Occasionally } \\
(\mathrm{n}=106)\end{array}$ & $\begin{array}{l}\text { Never } \\
(\mathrm{n}=45)\end{array}$ & $\mathrm{F}$ & $p$ \\
\hline $\begin{array}{l}\text { Learning } \\
\text { experience }\end{array}$ & $2.21 \pm 0.69$ & $2.23 \pm 0.69$ & $2.29 \pm 0.66$ & $2.46 \pm 0.61$ & $2.58 \pm 0.69$ & 2.48 & $.044^{*}$ \\
\hline$* p<0.05 * * p<0.01$ & & & & & &
\end{tabular}

To summarize, no statistically significant differences were found for respondents' background information except their previous experiences in online learning, indicating that selection bias, at least in terms of demographic characteristics, was not an influencing factor on students' EFL online learning experiences.

\subsection{Multiple Linear Regression Analysis of Students' Online EFL Learning Experience}

Table 7 shows the results of the multiple linear regression. Students' gender, type of university attended, education level, previous experience in online learning, online platforms, teaching method, interaction mode, learning process, class participation, and learning outcome were taken as independent variables, while students' perceived learning experience was taken as the dependent variable for stepwise regression analysis. The model identified the interaction mode (i.e., teachers check students attendance before class, call on students' names to answer questions in class, provide opportunities for group discussions, have students work on group project, give pop-up quizzes in class, show real-time videos) and students' perceived learning outcome (e.g., improve four skills in English, enhance general learning abilities, become more motivated and confident to learn English) as the most important factors influencing student perceived online EFL learning experiences. As shown in Table 7, the regression coefficient of interaction mode is $0.30(\mathrm{t}=6.54, \mathrm{p}=.000)$, suggesting that interaction mode has a significant positive impact on students' learning experience. The regression coefficient of learning outcome is 0.53 $(\mathrm{t}=12.81, p=.000)$, which means that the students' perceived learning outcome also has significantly positive influence on students' online EFL learning experiences. The automatic model identification shows that the interaction mode and the learning outcome can explain $60.4 \%$ of the variations in students' learning experiences, and the results are statistically significant $(\mathrm{F}=190.08, \mathrm{p}=0.000)$. In addition, the model of multicollinearity test found that the Vif values in the model were all less than 5, meaning that there is no collinearity issue; and the D-W value was close to 2 , suggesting that there is no correlation between the sample data, and the model is good.

Table 7. The multiple linear regression model $(\mathrm{n}=252)$

\begin{tabular}{|c|c|c|c|c|c|c|c|c|c|}
\hline & B & SE & Beta & $t$ & $p$ & VIF & $R^{2}$ & Adjusted $R^{2}$ & D-W Value \\
\hline Constant & 0.49 & 0.10 & - & 4.76 & $0.00 * *$ & - & & & \\
\hline Interaction mode & 0.30 & 0.05 & 0.30 & 6.54 & $0.00 * *$ & 1.32 & 0.60 & 0.60 & 2.09 \\
\hline Learning outcome & 0.53 & 0.04 & 0.59 & 12.81 & $0.00 * *$ & 1.32 & & & \\
\hline
\end{tabular}

$* p<0.05 * * p<0.01$

Overall, students' perceived experiences in their online EFL courses are quite good. Their perceived learning experiences can be categorized into five factors, namely, teaching platform, teaching method, interaction mode, teaching process, and learning outcome. Among the variables, interaction mode and learning outcome are found to be the most important in affecting students' perceived online learning experiences in their EFL courses.

\section{Discussion}

This study used questionnaire survey to investigate Chinese students' perceived online EFL learning experiences during the COVID-19 period. The results show that although schools were closed down, modern technology has 
granted new opportunities for English teachers to deliver effective EFL online courses during the lockdown. Students reported their overall positive experiences in EFL online learning and also showed optimistic attitudes towards EFL learning in the post-corona era.

\subsection{Overall Situation of Online EFL Learning in China during COVID-19}

The first research question deals with the overall situation of online EFL learning in China during the pandemic. As shown in the data, EFL courses are generally taught along with the school teaching calendar and are generally delivered in a synchronized fashion through platforms like Tencent Meeting, Tencent Classroom, or Zoom and school-developed platforms, complemented by instant messaging systems, such as WeChat, Tencent QQ, and Ding Talk for classroom interactions and instant feedback. Some teachers uploaded the learning materials and pre-recorded videos before the class sessions, and the class time is largely devoted to interactions and communications. Learning resources on MOOCs are seldom used for online learning by EFL teachers in China. As reported by several students, resources on MOOCs "are usually used for self-study purpose. Students are still required to attend online classes as scheduled." It seems that online EFL courses are somewhat taught in a traditional way, with the classroom location being the major difference. This may be because online teaching is implemented within a very short timeframe in which both school administrators and teachers were less prepared (MacIntyre, Gregersen, \& Mercer, 2020) for a complete alternative to how students should be taught and assessed, as well as how teachers' workload can be evaluated. This situation may have given rise to teachers' preference to adopting a rather conservative and traditional way of teaching through online platforms. Another reason could be that such a teaching mode can simulate the face-to-face classroom in which teachers can check students' attendance, supervise the learning process, modify teaching materials, promote interactions (Adnan \& Anwar, 2020), and better engage students in EFL learning (Martin \& Bolliger, 2018). However, despite EFL teachers' efforts to promote interaction by having students answer questions and holding discussions, students still preferred classroom teaching and complained that due to the instability of network connection, such a way of teaching "is less efficient because more time is needed for waiting and the pace of class is quite slow" (student response). Students also suggested that it would be beneficial for teachers to provide recorded teaching videos so that students could have access to the videos and view them as many times as needed.

Based on these considerations, a growing body of research has stressed the importance of using a "blended learning" (Davis \& Fill, 2007) or hybrid instructional approach that combines elements of e-learning with the traditional classroom environment. In some situations, blended learning may require students to complete online units prior to class meeting to ensure they share a common foundation of knowledge. This allows class sessions to go into greater depth with more targeted exercises and discussions. Post-class e-learning elements can also be used to maintain an ongoing dialogue about course-related topics through chats or discussion board postings. Blended learning may help to optimize instructional designs and maximize learning opportunities and achievements in both online and face-to-face environments. However, given the sudden change of educational mode, teachers' unpreparedness for online teaching, and EFL teachers' general lack of technology literacy, most EFL teachers in China opted for a traditional classroom but in an online setting. In other words, classroom is merely moved from the physical space to a virtual space, with many features of online education largely unused and under-explored.

\subsection{Students' Perceived Experiences in Online EFL Learning}

The second research question asks about students' perceived experiences in taking online EFL courses. As suggested from the results, students' perceived online EFL learning experiences can be viewed from multiple dimensions, including perceived experiences with the teaching platform, teaching method, interaction mode, teaching process, and learning outcome, corroborating previous findings that students' learning experiences are complex and multifaceted. As revealed from the results, students' perceived experiences in online EFL courses are pretty good and involved a relatively high level of engagement. This could be attributed to the course delivery modes and interactional strategies adopted by the EFL instructors to engage students in online teaching. As shown in the results, besides the university-endorsed online teaching platforms, EFL teachers in China prefer to use the instant messaging system such as WeChat or QQ to offer students immediate feedback as a supplementary to their livestreaming lectures, echoing with previous studies that instructors' feedback was significant in online education (e.g., Eom, Wen, \& Ashill, 2006; Paechter et al., 2010; Palmer \& Holt, 2010; Tichavsky, Hunt, Driscoll, \& Jicha, 2015), and was highly correlated with students' satisfaction (Fedynich, Bradley, \& Bradley, 2015; Horvat et al., 2015; Shea et al., 2003; Yang \& Durrington, 2010), learning outcomes (e.g., Alraimi et al., 2015; Damnjanovic et al., 2015; Eom, Wen, \& Ashill, 2006), and their engagement (e.g., Baker, 2010; Gray \& DiLoreto, 2016; Martin, Wang \& Sadaf, 2018) in online learning. More importantly, these timely feedbacks were individualized, making individual students' performance visible to the instructors, which was otherwise hidden in a face-to-face classroom (Hara \& Kling, 2000; Vonderwell, 2003). Given that many Chinese students are better at expressing themselves 
through written texts than in oral speech, responding to teachers' questions through WeChat or QQ granted students more opportunities to participate in class activities and to voice their opinions, which could also promote students' engagement in online learning.

Nevertheless, despite students' overall satisfaction with the online EFL courses, some students complained that the pace of the English courses was "too slow because the teacher wanted to be as interactive as in a face-to-face classroom." Therefore, based on students' general negative experiences with on-line real-time interactions and their welcoming attitudes toward the instant feedback opportunities afforded by the instant messaging systems, $58.33 \%$ of the participants suggested that taking courses in traditional classroom that is supplemented with online learning components, such as "learning multimodal supplementary materials online", "receiving teachers' timely feedback online", "having diverse forms of interaction opportunities" and "collaborating with peers online", would be the most effective way to learn a foreign language in the future. This indicates that the technological tools are yet to be recognized as the complete alternatives to physical classrooms. Their role is rather supplementary. For example, many students suggested that "teachers should make better use of online platforms and prepare multimodal learning materials for a variety of learners, which could be otherwise challenging in face-to-face classrooms." Other suggestions concerned the assessment method. Although students responded quite positively toward their experiences with the course assessment method, they suggested that "online learning should adopt a more flexible way of evaluation that places greater emphasis on students' daily performance."

These finding also bear implications for face-to-face classroom teaching. With the increasing prevalence of modern technology, students can easily have access to multimodal input in English, making EFL learning happen anytime and anywhere. This blurs the boundary of the traditional classrooms where students often receive unidirectional input from the instructors. Given the efficiency of knowledge transmission through internet, teachers are endowed with new missions to guide student learning, such as offering timely, individualized feedback, designing diversified tasks for students to use English, and answering students' specific questions. Therefore, a blended learning mode is necessary for effective English learning even in the post-corona era in which learning is goal-oriented, individualized, and co-constructed between teachers and students.

\subsection{Factors Influencing Chinese Students' EFL Online Learning Experiences}

The third question regards the influencing factors in Chinese students' experiences in online EFL learning. As suggested by the results, no statistically significant differences were found for respondents' background information except their previous experiences in online learning, indicating that students' individual variables play a less important role in affecting students' perceived experiences in online EFL learning. This finding somewhat contradicts previous studies (e.g., Alhamami, 2019; Chen \& Jia, 2020; Eom, Wen, \& Ashill, 2006; Paechter et al., 2010; Song et al., 2004; Tichavsky, Hunt, Driscoll \& Jicha, 2015) that highlighted students' individual differences in online learning. This is probably because previous studies mostly targeted students who took online courses for self-learning so that student-related characteristics seem to play an important role. However, this study also shows that as students experience more online self-learning, they tend to have better experiences with the online EFL courses during the pandemic. This could be because most EFL teachers in China adopted synchronized teaching mode in which students can have direct interaction with teachers, which is lacking in their previous online courses. This further suggests that the presence of teacher has an influence on students' perceived online learning experience (Martin, Wang, \& Sadaf, 2018; Shea et al., 2003). Among the factors identified in this study, interaction mode and learning outcome are found to be the most important in affecting students' perceived online learning experiences in their EFL courses. In general, students are positive about their EFL teachers' use of interaction mode in online teaching, including calling on students' names to answer questions, providing opportunities for group discussion, and giving pop-up quizzes in class. However, students also suggested that "diversified interaction methods should be used when learning online, such as online discussion board, text chat, breakout rooms for group discussion with teaching assistants being present, etc." Nevertheless, students' responses to the open-ended questions indicated that traditional classroom interaction is still favored.

As shown in the results, students perceived their gains in online learning as very important, which is not widely documented in previous literature. This may be because EFL courses in Chinese universities are required, which makes students greatly care about their learning outcomes. This also brings about the issue of assessment in online learning. As discussed above, EFL teachers tended to adopt the similar assessment method as in the traditional offline class, further indicating that in the large-scale implementation of online courses, the merits of online education were not fully explored, and online teaching was merely treated as an alternative to traditional classroom teaching. Compared with previous studies that highlighted the significance of online technology in promoting student learning (Al-Ghamdi, Almansoob \& Alrefaee, 2019; Daymont, Blau, \& Campbell, 2011; Medriano \& Bautista, 2020; Smith, 2005), this study presents an educational reality that when online education is obligatorily 
implemented in a large scale, especially at the national level, challenges from multiple aspects may emerge and joint efforts from a variety of stakeholders are needed.

\section{Conclusion}

Online learning represents an important, growing trend in the application of technology to facilitate learning, especially during the unexpected social crisis period. Through questionnaire survey, this study investigated students' perceived experience of online EFL courses during the COVID-19 pandemic. Despite the relatively small sample size, this study is significant in helping EFL teachers understand students' perceptions of their learning experiences in online English courses, which is beneficial for school administrators and teachers to design and deliver effective EFL courses with the help of modern technology. The findings provide important insights about learners' perceptions of online EFL learning and raise practical considerations for its implementation. Based on students' perceived experiences, we call for an English education move to "blended learning" (Davis \& Fill, 2007) which strives to balance the traditional classroom interaction, as well as online platforms and resources to maximize the teaching outcome and optimize students' online EFL learning experiences.

Findings from this study bear several implications for EFL teaching, especially in the post-corona era. For school administrators, it is of great impetus to improve the online teaching platforms to better serve the increasing demands for online education in the future. From students' perspective, more stable online platforms with diversified interaction modes are desired for effective online EFL courses. Also, carefully selected and multimodal learning materials that can suit diverse learning goals should be collected and made available online for better learning, and class time should be devoted to more interactive activities that can promote knowledge co-construction and application, as advocated in a blended-learning model. In addition, issues regarding how students are given credits for their online English learning and how teachers are evaluated based on their online teaching load should also be considered. It is also advisable for schools to adopt a more flexible and plausible policy for online learning, especially in the post-corona era, to better serve the increasing need for mass education. For teachers, it is important to improve their literacy in using technology and adopting diversified teaching methods to stimulate students' interest in learning and improve the effectiveness of teaching.

\section{References}

Adedoyin, O. B., \& Soykan, E. (2020). Covid-19 pandemic and online learning: the challenges and opportunities. Interactive Learning Environments. https://doi.org/10.1080/10494820.2020.1813180

Adnan, M., \& Anwar, K. (2020). Online learning amid the COVID-19 pandemic: Students' perspectives. Journal of Pedagogical Sociology and Psychology, 2(1), 2-8. https://doi.org/10.33902/JPSP.2020261309

Ajmal, M., Alrasheedi, S., Keezhatta, M. S., \& Yasir, G. M. (2020). COVID-19 and online English language teaching: Students' response and feedback. The Asian ESP Journal, 16(5), 39-65.

Al-Ghamdi, N. A., Almansoob, N. T., \& Alrefaee, Y. (2019). Pragmatic failure in the realization of the speech act of responding to compliments among Yemeni EFL undergraduates. The Southeast Asian Journal of English Language Studies, 25(4), 1-14. https://doi.org/10.17576/3L-2019-2504-14

Alhamami, M. (2019). Learners' beliefs about language-learning abilities in face-to-face \& online settings. International Journal of Educational Technology in Higher Education, 16. https://doi.org/10.1186/s41239-019-0162-1

Almazova, N., Krylova, E., Rubtsova, A., \& Odinokaya, M. (2020). Challenges and opportunities for Russian higher education amid COVID-19: Teachers' perspective. Education Sciences, 10. https://doi.org/10.3390/educsci10120368

Alraimi, K. M., Zo, H., \& Ciganek, A. P. (2015). Understanding the MOOCs continuance: The role oof openness and reputation. Computer \& Education, 80, 28-38. https://doi.org/10.1016/j.compedu.2014.08.006

Chen, W., \& Jia, W. (2020). Research on contributing factors of university students' online learning experience. Journal of East China Normal University (Educational Sciences), 7, 42-53.

Cole, A. W., Lennon, L., \& Weber, N. L. (2019). Student perceptions of online active learning practices and online learning climate predict online course engagement. Interactive Learning Environments. https://doi.org/10.1080/10494820.2019.1619593

Damnjanovic, V., Jednak, S., \& Mijatovic, I. (2015). Factors affecting the effectiveness and use of Moodle: students' perception. Interactive Learning Environments, 23(4), 496-514. https://doi.org/10.1080/10494820.2013.789062 
Davis, H. C., \& Fill, K. (2007). Embedding blended learning in a university's teaching culture: Experiences and reflections. British Journal of Educational Technology, 38(5), 817-828. https://doi.org/10.1111/j.1467-8535.2007.00756.x

Daymont, T., Blau, G., \& Campbell, D. (2011). Deciding between traditional and online formats: Exploring the role of learning advantages, flexibility and compensatory adaptation. Journal of Behavioral and Applied Management, 11, 156-179.

Dhawan, S. (2020). Online Learning: A Panacea in the Time of COVID-19 Crisis. Journal of Educational Technology Systems, 49(1), 5-22. https://doi.org/10.1177/0047239520934018

Eom, S. B., Wen, H. J., \& Ashill, N. (2006). The determinants of students' perceived learning outcomes and satisfaction in university online education: An empirical investigation. Decision Sciences Journal of Innovative Education, 4(2), 215-235. https://doi.org/10.1111/j.1540-4609.2006.00114.x

Fedynich, L., Bradley, K. S., \& Bradley, J. (2015). Graduate students' perceptions of online learning. Research in Higher Education Journal, 27, 1-13.

Gray, J. A., \& DiLoreto, M. (2016). The effects of student engagement, student satisfaction, and perceived learning in online learning environments. International Journal of Educational Leadership Preparation, 11(1), 98-119.

Hara, N., \& Kling, R. (2001). Student distress in Web-based distance education. EDUCAUSE Quarterly Magazine, 24(3).

Horvat, A., Dobrota, M., Krsmanovic, M., \& Cudanov, M. (2015). Student perception of Moodle learning management system: a satisfaction and significance analysis. Interactive Learning Environments, 23(4), 515-527. https://doi.org/10.1080/10494820.2013.788033

Khatoony, S., \& Nezhadmehr, M. (2020). EFL teachers' challenges in the integration of technology for online classrooms during coronavirus (COVID-19) pandemic in Iran. The Asian Journal of English Language \& Pedagogy, 8(2), 89-104.

Lin, C., Zhang, Y., \& Zheng, B. (2017). The roles of learning strategies and motivation in online language learning: A structural equation modeling analysis. Computers \& Education, 113, 75-85. https://doi.org/10.1016/j.compedu.2017.05.014

Lowenthal, P., Bauer, C., \& Chen, K.-Z. (2015). Student perceptions of online learning: An analysis of online course American Journal of Distance Education. https://doi.org/10.1080/08923647.2015.1023621

Luo, X., Ma, W., \& Yao, Y. (2020). A practical research of online teaching of college English after the outbreak of COVID-19 pandemic: Problems, measures and effects. Technology Enhanced Foreign Languages, 3, 30-35.

MacIntyre, P. D., Gregersen, T., \& Mercer, S. (2020). Language teachers' coping strategies during the Covid-19 conversion to online teaching: Correlations with stress, wellbeing and negative emotions. System, 94. https://doi.org/10.1016/j.system.2020.102352

Martin, F., \& Bolliger, D. U. (2018). Engagement matters: Student perceptions on the importance of engagement strategies in the online learning environment. Online Learning Journal, 22(1), 205-222. https://doi.org/10.24059/olj.v22i1.1092

Martin, F., Wang, C., \& Sadaf, A. (2018). Student perceptions of helpfulness of facilitation strategies that enhance instructor presence, connectedness, engagement and learning in online courses. The Internet and Higher Education, 37, 52-65. https://doi.org/10.1016/j.iheduc.2018.01.003

McNair-Crews, G. (2015). Investigating instructor perceptions of on-line teaching versus traditional classroom instruction. Unpublished Doctoral Dissertation. Walden University.

Nassoura, A. B. (2020). Measuring students' perceptions of online learning in higher education. International Journal of Scientific \& Technology Research, 9(4), 1965-1970.

Paechter, M., Maier, B., \& Macher, D. (2010). Students' expectations and experiences in e-learning: Their relation to learning achievements and course satisfaction. Computer \& Education, 54(1), 222-229. https://doi.org/10.1016/j.compedu.2009.08.005

Palmer, S., \& Holt, D. (2010). Students' perceptions of the value of the elements of an online learning environment: Looking back in moving forward. Interactive Learning Environments, 18(2), 135-151. https://doi.org/10.1080/09539960802364592 
Sakulwichitsintu, S., Colbeck, D., Ellis, L., \& Turner, P. (2015). Online peer learning: What influences the students' learning experience. IEEE 15th International Conference on Advanced Learning Technologies, 205-207. https://doi.org/10.1109/ICALT.2015.122

Sepúlveda-Escobar, P., \& Morrison, A. (2020). Online teaching placement during the COVID-19 pandemic in Chile: Challenges and opportunities. European Journal of Teacher Education, 43(4), 587-607. https://doi.org/10.1080/02619768.2020.1820981

Shea, P., Pickett, A., \& Pelz, W. (2003). A follow-up study of teaching presence in the online program. Journal of Asynchronous Learning Networks, 7(2), 61-80.

Smith, D. G. (2005). Teaching English with Information Technology. London: Modern English Publishing.

Song, L., Singleton, E. S., Hill, J. R., \& Koh, M. H. (2004). Improving online learning: Student perceptions of useful and challenging characteristics. Internet and Higher Education, 7, 59-70. https://doi.org/10.1016/j.iheduc.2003.11.003

Surani, D., \& Hamidah, H. (2019). Students perceptions in online class learning during the COVID-19 pandemic. International Journal on Advanced Science, Education, and Religion, 3(3), 83-95. https://doi.org/10.33648/ijoaser.v3i3.78

Thurmond, V. A., Wambach, K., Connors, H. R., \& Frey, B. B. (2002). Evaluation of student satisfaction: Determining the impact of a web-based environment by controlling for student characteristics. American Journal of Distance Education, 16(3), 169-190. https://doi.org/10.1207/S15389286AJDE1603_4

Tichavsky, L. P., Hunt, A. N., Driscoll, A., \& Jicha, K. (2015). It's just nice having a real teacher: Student perceptions of online versus face-to-face instruction. International Journal for the Scholarship of Teaching and Learning, 9(2). https://doi.org/10.20429/ijsotl.2015.090202

van der Kleij, F. M. (2019). Comparison of teacher and student perceptions of formative assessment feedback practices and association with individual student characteristics. Teaching and Teacher Education, 85, 175-189. https://doi.org/10.1016/j.tate.2019.06.010

Vonderwell, S. (2003). An examination of asynchronous communication experiences and perspectives of students in an online course: A case study. Internet and Higher Education, 6, 77-90. https://doi.org/10.1016/S1096-7516(02)00164-1

Wu, X., Yong, W., Dai, L., Jia, J., Wang, A., \& Miao, J. (2014). The study of the students' learning experience of the online course based on the Coursera pedagogical model. e-Education Research, 35(6), 11-17.

Yang, Y., \& Durrington, V. A. (2010). Investigation of students' perceptions of online course quality. International Journal on E-Learning, 9(3), 341-361.

Zhang, M., Yin, S., Nie, R., \& Tang, C. (2016). A comparative analysis of learners' continuous usage intention on Chinese and foreign MOOC platforms by examining learners' perceived experience: Using Coursera and Icourse 163 as sample. e-Education Research, 37(5), 44-49.

\section{Notes}

Note 1 . WeChat is the most widely used instant messaging and networking application in China. It has the function of forming small groups for specific communication purpose.

Note 2. "Double-First Class" initiative universities refer to a government initiative to bring Chinese universities up to international standards, with world-class teaching and disciplines. Project 211 is the Chinese government's endeavor aimed at strengthening the higher education institutions and key disciplinary areas as a national priority for the 21 st century. There are 112 universities in Project 211. Launched on May 4, 1998, Project 985 is a constructive project for founding world-class universities in the 21 st century. There are 39 universities in Project 985.

\section{Copyrights}

Copyright for this article is retained by the author(s), with first publication rights granted to the journal.

This is an open-access article distributed under the terms and conditions of the Creative Commons Attribution license (http://creativecommons.org/licenses/by/4.0/). 